\title{
THE POTENTIALS FOR TOURISM DEVELOPMENT IN THE MUNICIPALITY OF BUGOJNO BASED ON THE HILLARY DU CROS METHOD OF VALORIZATION
}

\author{
Dario Šakić ${ }^{1}$ \\ Miranda Čaveliš
}

\begin{abstract}
To properly plan for tourism development of great significance is existence of cultural, historical and natural heritage potentials in a certain area. That potential can be evaluated from several aspects. One of the aspects is the topic of this work: a tourist-geographical evaluation of the cultural - historical and natural heritage. This paper is therefore to analyze the potential of Bugojno for tourism development. A total of 30 cultural and natural potential attractions are analyzed. The aim of this paper is to point out the resources of Bugojno, applying the method of tourist valorization of natural and cultural resources by model Hilary du Cross. This method will identify the values of market attractiveness indicators, factors of importance when designing tourism products, cultural/natural importance and robustness of the site for tourism development. In terms of tourist valorization of a geographic area or destination, it is necessary to determine the elements of the natural, historical and cultural heritage. It is necessary to isolate the historical events and personalities associated with certain periods as well as properly review and know the current situation, with all the negatives, strengths and opportunities that this area offers. The results indicate that, in the long term, tourism can be an important economic sector in the region.
\end{abstract}

Keywords: Tourism potential, valorization, Hilary du Cros, Bugojno

\section{INTRODUCTION}

Attractive potentials (natural and anthropogenic elements of area) are one of the most important resources and the condition for the existence and survival of every tourist destination (Richards, 2002). The attraction is considered certain characteristics of the area (destination) that was directly specific towards location and motif of certain tourist activities (Weaver, 2006). To determine the attractive properties of tourism potential and destinations in general and formed an appropriate tourist offer, it is necessary to conduct the tourist valorization. It is a complex process of evaluating the space, content and appearance which characterize a particular destination, from a view of evaluation opportunities for tourism economy. This paper is therefore to analyze the potential of Bugojno for tourism development. The aim of this paper is to point out the resources of Bugojno, applying the method of tourist valorization of natural and cultural resources by model Hilary du Cross.

Geographical position, many natural beauties and great strategic importance in the region of Upper Vrbas valley allowed that this area is settled early in the past. Bugojno Municipality is one of 12 municipalities of the Central Bosnia Canton. Geographically, municipality is located in the Uskoplje valley with an altitude of $570 \mathrm{~m}$, and total area of municipality is $361 \mathrm{sq} \mathrm{km}$, therefore is considered as hilly and mountainous area. Relief of Bugojno is polyphase, polymorphic and polygenic what is result of a variety of endogenous and exogenous factors. Various forms of relief are distinguished, from the valley that covers the central part to the mountain ranges on the east and west, and the vast

\footnotetext{
${ }^{1}$ Faculty of Science and Education, University of Mostar, Mostar, Bosnia and Herzegovina; e-mail: dario.a.sakic@gmail.com.
} 
surface between and on the mountain ranges. In the northeast and east the most important mountains are those that bind Vranica Mountain (Nadkrstac, $2112 \mathrm{~m}$ ) and Mount Komar (Kamenjaš, 1510 m): Turčin, Hum, Radovan, Crni Vrh, Rudina, Kalin (1531 m) and Kaštel whose height exceeds $1500 \mathrm{~m}$, and they belong to the Mid-Bosnian Schist Mountains. The southern and south-western rim is followed by mountains that link Radusa mountain (Idovac $1956 \mathrm{~m}$ ) and Jelika mountain (1386 m): Lupoglava, Skrtska planina, Stožer, Šljaga i Mala Šljaga. In addition to these, around Bugojno are known plateau: Ravno Rostovo $(1095 \mathrm{~m})$, Otigošće $(1000 \mathrm{~m})$, Karalinka $(700 \mathrm{~m})$ and Demirovac (1765 $\mathrm{m})$.Climate in Bugojno is temperate continental with relatively warm summers and cold winters.Annual fluctuations in temperature are high, especially during the spring and fall.Frosts are expressed in early fall and late spring.Period of moderately warm months is a long and coincides with the period of vegetation (LEAP, 2007).Bugojno belongs to the Bosnian-Herzegovinian cities that have not grown out of the Ottoman urban tradition (Hadžibegović, 2004). The city lies at the intersection of three main roads, which connect it to all parts of the country: M-16 Bugojno - Kupres - Split, M-16.2 Jajce - Bugojno Prozor/Rama - Mostar, M-6 Bugojno - Novi Travnik. Bugojno is linked with the main road M-5 in Donji Vakuf that connects Bugojno - Travnik - Zenica - Sarajevo. The total length of constructed roads in Bugojno is $712 \mathrm{~km}$ (LEAP, 2007). The construction of the railway in 1895 caused rapid industrialization of the region, coal mines were open (Gracanica), forestry and leather processing start to develop (Saric, 2010). The backbone of the development of the municipality in the former Yugoslavia was based on industry, especially metal, electronic, leather, footwear, textile, mill - bakery industry, and also were represented agriculture, forestry, trade, catering and tourism. Personal and collective standards were above the average of Bosnia and Herzegovina, even the average of Yugoslavia. The development in material production has resulted in the rapid development in the field of social services. In this period new school facilities, cultural and sports center, football stadium, swimming complex, hotels, facilities for hunting and skiing and many others were built. Bugojno, as a modern and urbanized city, became the center of many cultural and sporting events, and the most important were International Grandmaster Chess Tournament, Yugoslav Biennial of puppetry and Festival of amateur theaters of Bosnia and Herzegovina. War devastation, the inefficient process of economic transition and the lack of development initiatives have led to the difficult economic situation in the municipality. Tourism as an economic sector in the previous period did not constitute an important area of development. In tourism, significant funds have not invested, except for development capacities for hunting after which Bugojno were known.

The current capacity of Bugojno for tourism are few sports and recreational centers such are the Cultural and Sport Center (KSC), built in 1983 with a sports hall with 3,500 seats, a theater hall with 550 seats, a cinema hall with 120 seats and an outdoor amphitheater, a tourist sport - recreation center "Karalinka", winter - recreational center "Rostovo", sport - recreational center "Potočani", pools in open, and numerous football and tennis sports fields.

Accommodation is offered in hotel Rostovo, boarding house Genex M, PUK Potočani, motel Heko, TRNC Karalinka, motel Alibey and mountain lodge Duboka with a total capacity of 311 beds (Proposal of development strategy of Bugojno, 2014). 
Tab. 1. Accommodation facilities and capacities

\begin{tabular}{|l|c|c|}
\hline \multicolumn{1}{|c|}{ Name of facility } & $\begin{array}{c}\text { Capacity } \\
\text { (beds) }\end{array}$ & $\begin{array}{c}\text { Number } \\
\text { of rooms }\end{array}$ \\
\hline Hotel Rostovo & 90 & 35 \\
\hline Boarding house Genex M & 24 & 8 \\
\hline Potočani & 36 & 18 \\
\hline Motel Heko & 45 & 28 \\
\hline Karalinka & 40 & 17 \\
\hline Motel Alibey & 26 & 10 \\
\hline Mountain lodge Duboka & 50 & 10 \\
\hline Total & $\mathbf{3 1 1}$ & $\mathbf{1 2 6}$ \\
\hline
\end{tabular}

Source: Proposal of development strategy of Bugojno, 2014

The Commission to Preserve National Monuments has declared six sites as national monuments: the archaeological site of Crkvina (Grudine), the archaeological site of the prehistoric hillfort settlement Pod, historical building Rustempašić tower, a historic area of Old town Vesela Straža, remains of the historic building Sulejmanpašić tower and sepulchral ensemble Mausoleum Malkoč and Skenderpašić (The Commission to Preserve National Monuments, 2005, 2006, 2007).

The geographical location, favorable climate with warm summers and cold winters, many water sources, the deep woods of Koprivnica, a tradition in the industry and many other resources are part of the benefits of Bugojno, whose long-term priorities are economic recovery and sustainable development. Mountain areas represent very significant natural tourist motifs, and if you are close to major urban areas - are extremely important excursion - recreational function (Marušić, 1977).

\section{METHODS}

Natural and cultural resources are not only aesthetic, but also economic value in a particular area, and they should be evaluated to provide the basis for the creation of value tourist products (Pantović, Stamenkovic, 2013).In order to develop any type of tourism in a particular location it is necessary to carry out the processes of valorization and evaluation, otherwise, could lead to negative effects.Tourism valorization will determine what potential Bugojno has.In the tourism industry, there are several different types of valorization.In this paper, a model of Hilary du Cros (du Cros, 2010) is used. Since the model is intended for cultural resources, in this paper are evaluated and natural values, therefore the model is modified to a small extent.During the valorization, two groups of sub-indicators are evaluated: the tourism sector (market appeal of cultural/natural resources and factors of importance when designing tourism products) and sector management of cultural/natural resources (cultural/natural significance and robustness). The maximum total value of indicators from both groups is 60 . Within the market appeal of cultural or natural resources, following sub-indicators were evaluated: good ambience, is well known outside the local area, whether it is good national symbol, that you can tell an interesting story, whether it has a certain good qualities which differentiate it clearly from the surrounding goods, whether it is attractive for special needs, whether it is complementary to other products at the destination or the region, as a tourist activity in the region, and whether the destination is associated with culture.From important factors when designing tourism products were evaluated good access, transport 
of goods to the population center, proximity to other cultural/natural attractions, and service facilities.

For every cultural and natural asset are made conclusions of the sub-indicators of market attractiveness for the tourism sector. Depending on the total score, natural/cultural asset is placed in three categories: from 0 to 20 have poor, 21 to 40 have medium and 41 to 60 have a high appeal.Within the cultural/natural significance were evaluated the aesthetic, historical, educational, social and scientific research value, rarity of the asset on the destination or region, and representativeness of asset.Within robustness were evaluated the sensitivity of the asset, state of repair, the existence of a asset management plan, regular monitoring and maintenance, the potential for ongoing investment and consulting the key stakeholders, the possibility of negative impact of a large number of visitors to the physical condition of the property and the possibility of negative impact of modification.And in this part of the assessment for each asset was made a conclusion on the sub-indicators for the management of cultural or natural assets and robustness.Depending on the overall score, assets are placed in categories. From 0 to 20 have a small, 21 to 40 have a moderate and 41 to 60 have a high value.After the analysis, a "matrix of market attractiveness/robustness" with a 9-cell is set up. For every cultural and natural asset it is determined to which cell it belongs, depending on the scores that are previously were assigned in the process of evaluation.The cells are defined as follows: M $(1,1)$ - high value of the cultural/natural significance/robustness indicators and low market attractiveness, M $(1,2)$ - high value of the cultural/natural significance/robustness indicators and medium market attractiveness, M (1,3) - high value of the cultural/natural significance/robustness indicators and high market attractiveness, $M(2,1)$ - the medium value of the cultural/natural significance/robustness indicators and low market attractiveness, M $(2,2)$ - the medium value of the cultural/natural significance/robustness indicators and medium market attractiveness, $\mathrm{M}(2,3)$ - the medium value of the cultural/natural significance/robustness indicators and high market attractiveness, $M(3,1)$ - a small indicator value of the cultural/natural significance/robustness indicators and small market attractiveness, M $(3,2)$ - a small of the cultural/natural significance/robustness indicators and medium market attractiveness and $\mathrm{M}(3,3)$ - a small of the cultural/natural significance/robustness indicators and high market attractiveness. 
Tab. 2. Sub-indicators of valorization and scoring board

\begin{tabular}{|c|c|c|c|}
\hline Tourist sector & Grades & $\begin{array}{c}\text { Natural/Cultural } \\
\text { heritage management }\end{array}$ & Grades \\
\hline $\begin{array}{l}\text { Market appeal } \\
\text { Ambiance (natural/cultural) } \\
\text { Well-known outside local area } \\
\text { Significant national symbol } \\
\text { Can tell an ,interesting“ story - } \\
\text { evocative place } \\
\text { Has some aspect to distinguish it } \\
\text { clearly from nearby assets or } \\
\text { attractions } \\
\text { Appeals to special needs } \\
\text { Complements other tourism } \\
\text { products in area } \\
\text { Tourism activity in the region } \\
\text { Destination associated with } \\
\text { nature/culture } \\
\text { Product design needs } \\
\text { Accessibility } \\
\text { Transport } \\
\text { Number natural/anthropogenic } \\
\text { nearby values } \\
\text { Service benefits }\end{array}$ & $\begin{array}{l}0-5 \\
0-5 \\
0-5 \\
0-5 \\
0-5 \\
0-5 \\
0-5 \\
0-5 \\
0-5\end{array}$ & $\begin{array}{l}\text { Natural/cultural significance } \\
\text { Aesthetic value } \\
\text { Historical value } \\
\text { Educational value } \\
\text { Social value } \\
\text { Scientific potential/research } \\
\text { value } \\
\text { Rareness } \\
\text { destination/region } \\
\text { Representativeness } \\
\text { Robustness } \\
\text { Fragility } \\
\text { State of repair } \\
\text { Management plan or policy in } \\
\text { place } \\
\text { Regular monitoring and } \\
\text { maintenance } \\
\text { Potential for ongoing } \\
\text { involvement and consultation } \\
\text { of key stakeholders } \\
\text { Possibility of negative } \\
\text { impacts of high visitation on } \\
\text { physical state } \\
\text { Possibility of modification (as } \\
\text { part of product development) } \\
\text { to have not negative impact } \\
\text { on physical state }\end{array}$ & $\begin{array}{l}0-4 \\
0-4 \\
0-5 \\
0-5 \\
0-5 \\
0-5 \\
0-5\end{array}$ \\
\hline
\end{tabular}

Source: Bjeljac et al.,2013

Tab. 3. Matrix of market attractiveness and robustness

\begin{tabular}{|c|c|c|c|}
\hline \multirow{3}{*}{ Robustness } & $\mathrm{M}(1,1)$ & $\mathrm{M}(1,2)$ & $\mathrm{M}(1,3)$ \\
\cline { 2 - 4 } & $\mathrm{M}(2,1)$ & $\mathrm{M}(2,2)$ & $\mathrm{M}(2,3)$ \\
\cline { 2 - 4 } & $\mathrm{M}(3,1)$ & $\mathrm{M}(3,2)$ & $\mathrm{M}(3,3)$ \\
\hline \multicolumn{3}{|c|}{ Market attractiveness } \\
\hline
\end{tabular}

Source: Hilary du Cros, 2010

\section{RESULTS}

The paper analyzes 30 resources and potentials for tourism development in the area of Bugojno, from cultural monuments, archaeological sites, areas reserved for sport and recreation forms of tourism to areas with outstanding natural value. 

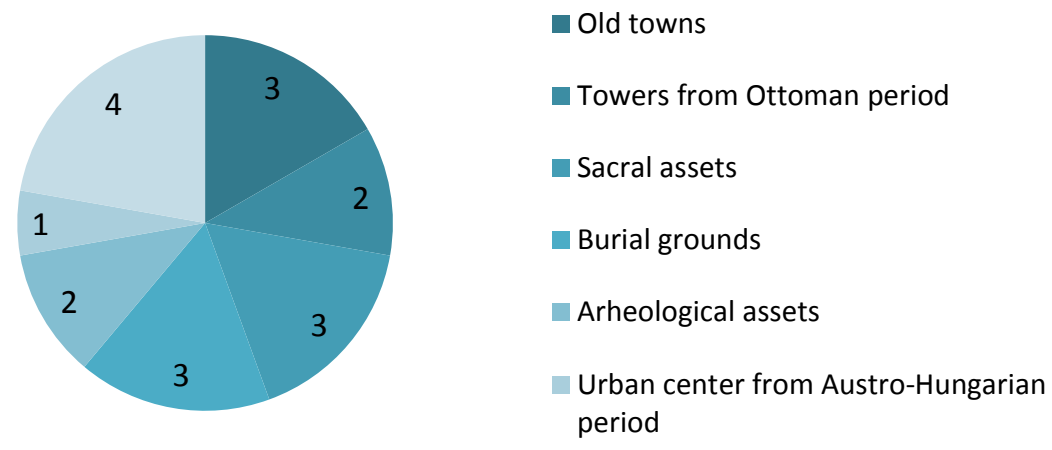

Fig. 1. Number and type of cultural assets valorized in this paper

Cultural assets that were evaluated are the old towns of Vesela Straza, Susid and Kastel, Sulejmanpasic and Rustempasic tower, the Roman Catholic Church of St. Anthony of Padua, Sultan Ahmed mosque and the Serbian Orthodox Church of the Nativity of the Virgin Mary, the Jewish cemetery, Malkoc and Skenderpasic mausoleum, urban center from the period of the Austro - Hungarian Empire, archaeological sites Pod and Crkvina (Grudine), Tito's villa in Gorica and Koprivnica, memorials from National liberation movement in Prsljani and Kozvarice as well as medieval tombstones.Tombstones are located at several locations and in the following table is their common value. Because of conservation, favorable location in the city center, proximity of services, sacral places were given the highest rating. They are suitable for the development of religious tourism, especially during June, when it is celebration of the patron saint of Bugojno and Ajvatovica, the biggest Muslim pilgrimage site in Europe, which following events also taking place in the area of Bugojno. The urban center of the Austro-Hungarian period have high scored because of its aesthetic value and conservation, while Tito's villas, although in ruins, get the good scores because they are well-known outside local area and they have good potential for development of memorial tourism.

Natural resources, potentials and areas reserved for sport and recreational forms of tourism that were analyzed are geomorphologic phenomenaKameni svatovi, Valley of caves, Japaga pit, thermomineral spring Vruca voda mineral spring Zlatarica, Ravno Rostovo, Koprivnica, Duboka, Karalinka, Gorica, and the lakes Radovan and Zanesovici.

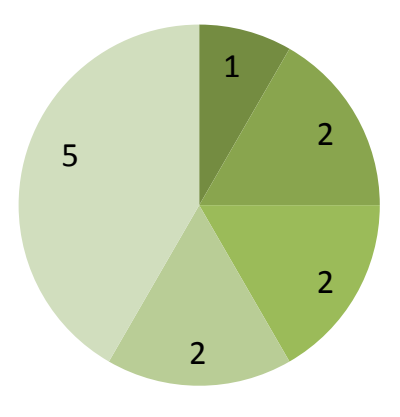

Geomorphic fenomena

- Caves and pits

Springs

Lakes

Landscapes of exceptional natural values

Fig. 2. Number and type of natural assets valorized in this paper 
Ravno Rostovo has the highest value of market appeal due to existing tourism activities, mostly in winter tourism, and the existence of ethno village "Babic" suitable for rural and eco tourism.In addition, the high scores got Karalinka, which is located near the city center, and has a sport and recreational elements. The ambiance is nice, because it is located on a plateau, surrounded by fir forests. It is suitable for adventure tourism, walking and cycling.Other localities have received lower scores due to the greater distance from the population center, weak road communication, unregulated parking spaces, and proximity to potential minefields.

High attractiveness (41 - 60) of sub-indicators of the market appeal of cultural/natural asset have destinations: the church of St. Anthony of Padua (50), Sultan Ahmed Mosque (50), the Church of the Nativity of the Virgin Mary (50), the urban center of the Austro-Hungarian period (52), Ravno Rostovo (50), Jewish Cemetery and Malkoc and Skenderpasic mausoleum (41) and Tito's villa Gorica (44).

From evaluated assets, 20 of them have medium value of cultural/natural significance/ robustness indicators and medium market attractiveness indicators (matrix M (2.2)), eight sites have moderate values of cultural/natural significance/robustness indicators and high market attractiveness (M (2.3)), and two sites have little value of cultural/natural significance/robustness indicators and medium market attractiveness (M (3.2)).

Tab. 2. Total grades for market attractiveness and robustness with matrix

\begin{tabular}{|c|c|c|c|c|c|}
\hline$\dot{\mathbf{Z}}$ & Name of destination & Locality & $\begin{array}{c}\text { Market } \\
\text { attractiveness }\end{array}$ & Robustness & Matrix \\
\hline 1. & $\begin{array}{l}\text { Old town Vesela } \\
\text { Straza }\end{array}$ & Vesela & 28 & 21 & $M(2,2)$ \\
\hline 2. & Old town Susid & Kordici & 22 & 20 & $\mathrm{M}(3,2)$ \\
\hline 3. & Old town Kastel & Harambasici & 23 & 19 & $\mathrm{M}(3,2)$ \\
\hline 4. & Sulejmanpasic' tower & Odzak & 32 & 22 & $\mathrm{M}(2,2)$ \\
\hline 5. & Rustempasic' tower & Odzak & 33 & 22 & $\mathrm{M}(2,2)$ \\
\hline 6. & Thombstones & $\begin{array}{l}\text { Various } \\
\text { locations }\end{array}$ & 28 & 23 & $M(2,2)$ \\
\hline 7. & $\begin{array}{l}\text { Church of St. } \\
\text { Anthony of Padua }\end{array}$ & Centar & 50 & 31 & $\mathrm{M}(2,3)$ \\
\hline 8. & $\begin{array}{l}\text { Sultan Ahmed } \\
\text { Mosque }\end{array}$ & Centar & 50 & 31 & $M(2,3)$ \\
\hline 9. & $\begin{array}{l}\text { Church of the } \\
\text { Nativity of the Virgin } \\
\text { Mary }\end{array}$ & Cipuljic & 50 & 31 & $M(2,3)$ \\
\hline 10. & Jewish cemetery & Gromile & 41 & 26 & $M(2,3)$ \\
\hline 11. & $\begin{array}{l}\text { Malkoc' and } \\
\text { Skenderpasic' } \\
\text { Mausoleum }\end{array}$ & Kopcic & 41 & 25 & $M(2,3)$ \\
\hline 12. & $\begin{array}{l}\text { The urban center } \\
\text { from the Austro- } \\
\text { Hungarian period }\end{array}$ & Centar & 52 & 32 & $M(2,3)$ \\
\hline
\end{tabular}




\begin{tabular}{|c|c|c|c|c|c|}
\hline 13. & $\begin{array}{l}\text { Archaeological site } \\
\text { Pod }\end{array}$ & Cipuljic & 35 & 23 & $\mathrm{M}(2,2)$ \\
\hline 14. & $\begin{array}{l}\text { Archaeological site } \\
\text { Crkvina (Grudine) }\end{array}$ & Cipuljic & 33 & 22 & $\mathrm{M}(2,2)$ \\
\hline 15. & Tito's villa Gorica & Sultanovici & 44 & 26 & $\mathrm{M}(2,3)$ \\
\hline 16. & $\begin{array}{l}\text { Tito's villa } \\
\text { Koprivnica }\end{array}$ & Koprivnica & 40 & 26 & $\mathrm{M}(2,2)$ \\
\hline 17. & Memorial Prsljani & Prsljani & 31 & 29 & $\mathrm{M}(2,2)$ \\
\hline 18. & Memorial Kozvarice & Koprivnica & 32 & 29 & $\mathrm{M}(2,2)$ \\
\hline 19. & $\begin{array}{l}\text { Geomorphic } \\
\text { phenomena Kameni } \\
\text { svatovi }\end{array}$ & Kordici & 37 & 26 & $\mathrm{M}(2,2)$ \\
\hline 20. & Valley of caves & Duboka & 29 & 23 & $\mathrm{M}(2,2)$ \\
\hline 21. & Pit Japaga & Kalin & 28 & 23 & $\mathrm{M}(2,2)$ \\
\hline 22. & $\begin{array}{l}\text { Thermomineral } \\
\text { spring Vruca voda }\end{array}$ & $\begin{array}{l}\text { Kalin - } \\
\text { Rudina }\end{array}$ & 34 & 26 & $\mathrm{M}(2,2)$ \\
\hline 23. & $\begin{array}{l}\text { Mineral spring } \\
\text { Zlatarica }\end{array}$ & $\begin{array}{l}\text { Kalin - } \\
\text { Rudina }\end{array}$ & 33 & 26 & $\mathrm{M}(2,2)$ \\
\hline 24. & Ravno Rostovo & \begin{tabular}{|l|} 
Ravno \\
Rostovo \\
\end{tabular} & 50 & 33 & $\mathrm{M}(2,3)$ \\
\hline 25. & Koprivnica & Koprivnica & 29 & 28 & $\mathrm{M}(2,2)$ \\
\hline 26. & Duboka & Duboka & 39 & 31 & $\mathrm{M}(2,2)$ \\
\hline 27. & Karalinka & Karalinka & 40 & 29 & $\mathrm{M}(2,2)$ \\
\hline 28. & Gorica & Sultanovici & 32 & 25 & $\mathrm{M}(2,2)$ \\
\hline 29. & Lake Radovan & Radovan & 25 & 24 & $M(2,2)$ \\
\hline 30. & Lake Zanesovici & Zanesovici & 38 & 26 & $\mathrm{M}(2,2)$ \\
\hline
\end{tabular}

For tourism development the most suitable are assets that are assigned to the matrix $\mathrm{M}(1,3)$ and $\mathrm{M}(2,3)$ after evaluation of all sub-indicators.In such assets valuation does not require additional preparation period for their incorporation into the tourism product (Popovic, 2013).

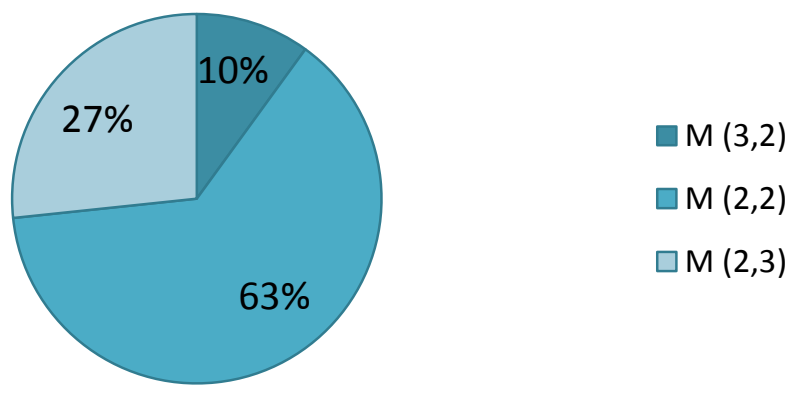

Fig. 3. Matrix of market attractiveness and robustness 
Limit that the municipality is facing is pollution of forest areas by landmines; their removal is a prerequisite for bringing space to final use. According to BH MAC in Bugojno municipality there are $16115 \mathrm{sq} \mathrm{km}$ of suspected areas that are polluted with landmines.

The area of Bugojno is a very complex tourism environment, with many historical and natural tourist motives which, through proper management can fully present to tourists with its substantial and diverse offer.Historical events that took place in this region were reflected in the life of the people in this municipality. Those events created and left legacy of spiritual and material culture, which today represent one of the factors of tourism development in this region, like prehistoric monuments, medieval towns and the tombstone , buildings from the Ottoman and Austro-Hungarian period and the legacy from the period of the second Yugoslavia.After the tourist valorization is done, sub-indicatorssuggest that the ancient cities, prehistoric monuments, religious facilities and tombstones tourist attractive and suitable for the development of tourism, special cultural, but with adaptation and additional investments. The existence of thermo-mineral water, Vruca voda, and mineral spring Zlatarica, provides the basis for the development of health tourism.According to Sibinovic and Belij (2010) thermal mineral water, and climate as a health factor, are the basis that needs to be methodically, systematically and long-term research and properly evaluate.Greffe (2004) considers that the evaluation of heritage leads to new jobs, and comes to the conclusion that investment in heritage is more sustainable if it is implemented in areas where heritage plays a secondary role and level of economic integration is high.Natural resources of the municipality, such as the rich forest areas of Koprivnica, Duboka, plateau Karalinka and Rostovo, and Lakes Zanesovici and Radovan provide opportunities for the development of several types of tourism, from ecotourism, rural tourism, adventure, fishing, hunting, the skiing, swimming, etc.According to the Draft of Strategy of Bugojno (2014), the Upper Vrbas region, including area of Bugojno, is positioned as rural - natural oasis that offers a wealth of experience in nature and idyllic atmosphere that permeates the river Vrbas.Natural resources are the basis for the development of tourism in a region (Pantovic, Stamenkovic, 2013).Accommodation in the vicinity of the stronger tourist centers such as Kupres, Jajce, Travnik and Vlasic opens up the possibility for a tourist to connect with the wider region and the creation of products that can be used to link and network these areas.

\section{CONCLUSIONS}

The aim of this study was to determine the attractiveness of the market and the robustness of the potentials for tourism development of Bugojno based on methods developed by Hilary du Cros.A large number of cultural and natural resources have the potential to become a tourist product for the development of tourism because they show to us in a unique waya rich and diverse history of the area, customs, way of life, natural resources and enable the improvement and enrichment of the tourist offer.All tourist sites have expressed natural geographic benefits, and in most locations are interwoven elements of historical, natural, recreational and other values that give full justification to activate and create content of tourism.Bugojno has a big tourist importance for Bosnia and Herzegovina, and its values are reflected in a many urban green areas, forest resources, lots of native wildlife, beautiful rivers, tributaries and lakes, natural beauties, cultural and historical monuments, but also the hospitality of the hosts, that will classified Bugojno as very attractive and high-quality tourist destination.Natural and cultural resources of the 
municipality are the basis for the development of tourism and tourist offer should be based on these resources. Analysis of the current situation showed that the municipality has the potential for tourism development, but they need some investment and the establishment of a tourism development strategy and adequate protection of natural and cultural heritage.

\section{ACKNOWLEDGEMENTS}

We thank Professor Snjezana Musa, PhD for assistance and for comments that greatly improved the manuscript. She provided insight and expertise that greatly assisted the research.

\section{REFERENCES}

Bjeljac, Z., Brankov, J., Jovicic, D., Curcic, N., Terzic, A. (2013): Valorization of natural and anthropogenic tourist potentials in undeveloped regions of transition countries. TTEM - Journal of society for development of teaching and business process in new net environment in B\&H. Vol. 8, No. 3, 1237 - 1249.

Cros, Hilary du (2000): Planning for sustainable cultural heritage tourism in Hong Kong. Final Report to the Lord Wilson Heritage Trust Council. SAR

Greffe, X. (2004): Is heritage an asset or a liability? Journal of Cultural heritage, vol 5, Issue $3.301-309$.

Hadžibegović, Ilijas (2004): Bosanskohercegovački gradovi na razmeđu 19. $i$ 20. st. Institut za istoriju. Sarajevo. 354 pp.

Marušić, Branka (1977): Izbor i ocjena lokacije za turističko aktiviranje Kozare. Geografski pregled sv. XXI. Geografsko društvo BiH, Sarajevo. 91-111

Pantović, M., Stamenković, I. (2013): Tourism potential valorization of the river Danube in Novi Sad and its environment based on the Hilary du Cros model. European Researcher, vol. 59, No. 9 -2. $2295-2305$

Popović, M. (2013): Kulturno - turistička valorizacija istorijskog jezgra Cetinja. Godišnjak Fakulteta za kulturu i medije, br. 5

Richards, G. (2002): Tourism attraction systems: Exploring cultural behavior. Annals of Tourism research. 29 (4), $1048-1064$.

Sarić, Samija (2010): Bugojno i njegova okolina u vrijeme austro-ugarske uprave (18781918). Buybook. Sarajevo. 346 str.

Sibinović, M., Belij, M. (2010): Termalne vode Rgoške banje kao osnov razvoja banjskog turizma knjaževačkog kraja. Glasnik srpskog geografskog društva, sv. XC, br. 1. 333 - 340

Weaver, D. (2006): Sustainable tourism: theory and practice. Oxford: Elsevier Butterworth - Heinemann 


\section{SOURCES}

Bosnia and Herzegovina Mine Action Center, 2015

The Commission to Preserve National Monuments (2005): Decision declaringarchaeological site Crkvina (Grudine) inCipuljic, Bugojno is a national monument. Official gazette of Bosnia and Herzegovina 75/08.

The Commission to Preserve National Monuments (2005): Decision declaringarchaeological site Pod, prehistoric hillfort in Bugojnois a national monument. Official gazette of Bosnia and Herzegovina 75/08.

The Commission to Preserve National Monuments (2005): Decision declaring historic area of old town Vesela Straža in Bugojno is a national monument. Official gazette of Bosnia and Herzegovina 42/06.

The Commission to Preserve National Monuments (2006): Decision declaringhistoric building of Rustempasic towerin Odzak, Bugojno is a national monument. Official gazette of Bosnia and Herzegovina 105/06.

The Commission to Preserve National Monuments (2007): Decision declaring historic building of Sulejmanpasictower in Bugojnois a national monument. Official gazette of Bosnia and Herzegovina 36/07.

The Commission to Preserve National Monuments (2007): Decision declaringburial ground of Turbe Malkoc and Skenderpasicin Kopcic, Bugojno is a national monument. Official gazette of Bosnia and Herzegovina 88/07.

Local ecological action plan for Bugojno municipality (LEAP), 2007

Development strategy proposal for Bugojno municipality, 2014 